\title{
Pengaruh Pola Kredit Pengadaan Bibit Terhadap Kinerja Pengembangan Sapi Potong Pada Peternak Kecil Di Provinsi Jambi
}

\author{
Husni Jamal \\ Balibangda Provinsi Jambi
}

\begin{abstract}
The research was aimed to study the influence of credit schemes in providing breeding stack on the performance of beef cattle development for smallholder farmers. The research was carried out through a survey on 183 respondents who involved the beef cattle development project. They were lacated in three Development Areas of Beef Cattle in Jambi Province: Singkut, Regency of Sarolangun; Pamenang, Regency of Merangin; and Kuamang Kuning, Regency of Bungo. The respondents were divided into two groups of credit recipients, who received credit with FI (Full in-kind) and CC (Cash Credit) schemes. Results showed that there were more heifers obtained from CC scheme (50\%) to become acceptors of Artificial Insemination program than that of obtained from FI scheme (7\%). Birth Rate of the heifers from FI scheme $(0.51 \pm 0.18$ heads/year) was significantly lower than that from CC scheme $(0,84 \pm 0,80$ heads/year). Mortality Rate of calves from CC scheme $(1,7, \%)$ was lower than that from FI scheme $(6,5, \%)$. The number of respondents from $\mathrm{CC}$ scheme who planted grasses $(71 \%)$ and offered concentrate for their animals ( $46 \%$ ) was higher than that form from $F I(28 \%$ and $16 \%$, respectively). Respondents received CC scheme showed more positive Attitude toward Beef Cattle Development than thase received FI scheme. It was concluded that CC scheme in providing breeding stocks for smallholder farmers in Jambi Province had a better influence on the performance of beef cattle development than FI scheme did. Therefore, the researcher recommended to the government to reevaluate the existence of F1 scheme.
\end{abstract}

Key words: credit scheme, beef cattle development

\section{Pendahuluan}

Pengembangan sapi potong di Provinsi Jambi sepenuhnya masih tergantung pada peternak kecil. Guna membantu para peternak dalam memperoleh modal untuk pengadaan bibit maka pemerintah telah memfasilitasi kredit dengan berbagai pola. Secara garis besar pola kredit yang disalur terdiri dari dua yaitu gaduhan dan tunai. Pola gaduhan yang diterapkan adalah Gaduhan Murni (Full Inkind), dimana petani menerima kredit berupa ternak dan mengembalikan pinjamannya dalam bentuk ternak hasil keturunannya. Pola pengembalian yang diterapkan adalah 1-2-5 yaitu penerima satu ekor betina mengembalikan dua ekor keturunannya dalam jangka waktu lima tahun. Pola inilah yang paling umum diterapkan melalui berbagai proyek pengadaan ternak sapi potong pemerintah sejak tahun 1970-an.

Sedangkan pola tunai antara lain dilaksanakan melalui penyaluran dana PMUK (Penguatan Modal Usaha Kelompok), sebelumnya disebut sebagai BPLM (Bantuan Pinjaman 
Langsung Masyarakat) (Anonim, 2006). Penyaluran dana PMUK dilakukan melalui kelompok secara tunai, kemudian kelompok meminjamkan dana tersebut kepada anggotanya untuk pengadaan bibit ternak. Anggota mengembalikan kredit kepada kelompok dalam jangka waktu dan besar jasa pinjaman sesuai kesepakatan kelompok.

Guna melihat sejauh mana kedua pola kredit yang telah diterapkan oleh pemerintah dalam penyediaan bibit sapi potong untuk petani kecil di Provinsi Jambi ini berpengaruh terhadap kinerja pengembangan ternak, khususnya untuk tujuan pembibitan, maka dilakukan penelitian ini. Indikator kenerja pengembangan sapi potong yang diamati mengacu pada Trilogi Peternakan yang dicetuskan oleh Saragih (1998) yang terdiri dari Bibit, Pakan dan Manajemen (Breeding, Feeding and Management). Melalui penelitian ini diharapkan dapat dirumuskan sejumlah masukan bagi pemerintah guna penetapan kebijakan yang dapat lebih mendorong pengembangan peternakan ke depan. khususnya dalam penyediaan kredit pengadaan bibit sapi potong untuk peternak kecil.

\section{Materi Dan Metode}

Disain penelitian yang digunakan adalah survey terhadap sampel yang paling mewakili populasi. Pola kredit yang dikaji terdiri dari dua yaitu gaduhan, yang selanjutnya disebut GM (Gaduhan Murni) serta pola tunai melalui penyaluran dana PMUK yang selanjutnya disebut KT (Kredit Tunai). Pada pola GM peternak menerima kredit dalam bentuk bibit ternak dan mengembalikan kredit tersebut dengan ternak hasil keturunannya. Sedangkan pada pola KT peternak menerima kredit dalam bentuk uang untuk dibelikan bibit ternak kemudian mengembalikannya dalam bentuk uang atau ternak yang dinilai dengan uang, sesuai kesepakatan kelompok.

Lokasi penelitian ditentukan secara purposive pada Kawasan Pengembangan Sapi Potong di Provinsi Jambi yang mendapatkan penyaluran kredit dengan kedua pola yang dikaji. Responden pola GM adalah petani penerima kredit ternak sapi bibit dari pemerintah dengan menggunakan pola gaduhan. Responden pola KT adalah anggota kelompok tani penerima PMUK yang betul-betul mencerminkan penyaluran kredit dengan pola tunai, dimana anggota kelompok betul - betul mempunyai kesempatan untuk memilih ternak yang akan dibeli, baik oleh kelompok maupun oleh anggota secara perorangan. Atas dasar ketentuan tersebut maka ditetapkan tiga lokasi penelitian yaitu Kawasan Singkut, Kabupaten Sarolangun, Kawasan Pamenang, Kabupaten Merangin; dan Kawasan Kuamang Kuning, Kabupaten Bungo. Jumlah responden dalam penelitian ini sebanyak 183 KK (Kepala Keluarga) yang terdiri dari $90 \mathrm{KK}$ responden penerima GM dan $93 \mathrm{KK}$ responden penerima KT.

Data primer dikumpulkan pada akhir Mei 2006 melalui wawancara dengan responden dan pengamatan lapangan. Penentuan responden dilakukan melalui metode snowball (Nasution, 2004). Wawancara dilakukan di kediaman responden dengan melibatkan anggota keluarga lain yang dianggap berperan dalam proses 
pengambil keputusan dan pengelolaan usahatani di dalam keluarga tersebut. Hal ini mengacu pada saran Soekartawi et al (1986) bahwa dalam penelitian usahatani, wawancara dengan lebih dari satu anggota keluarga akan memberikan hasil yang lebih memuaskan. Data primer yang dikumpulkan mencakup dua aspek utama yaitu: (1) identitas serta berbagai informasi yang berkaitan dengan aktivitas pengembangan sapi potong responden; dan (2) sikap responden terhadap pengembangan sapi potong yang ia lakukan. Data pada aspek pertama dikumpulkan melalui sejumlah pertanyaan yang disusun dalam format pertanyaan terbuka maupun pilihan. Sedangkan untuk data aspek kedua dibuat dalam format summated rating atau Skala Likert sebagaimana yang disarankan oleh Suryabrata (1998); Azwar (1995); dan Ancok (1997) dengan menggunakan tiga pilihan jawaban yaitu Setuju, Ragu - ragu dan Tidak Setuju.

Data yang telah dikumpulkan diolah dengan menggunakan program SPSS 12.0 for Windows. Untuk mendapatkan kesimpulan mengenai keadaan responden maka data diolah dengan sejumlah alat uji yang tersedia pada program tersebut meliputi Descriptive Statistics, IndependentSamples $T$ Test dan Reliability Analysis. Pemilihan alat uji yang sesuai dengan tujuan penelitian dan data yang tersedia mengacu pada petunjuk mengenai penggunaan program SPSS yang disusun oleh Kuswadi dan Mutiara (2004); dan Nugroho (2005); serta buku teks statistik Carlson dan Thorne (1997).

\section{Hasil Dan Pembahasan}

Bibit

\section{a. Peningkatan Mutu Genetis Bibit}

Ternak yang dipelihara responden tidak hanya terbatas pada ternak yang diperoleh dari kredit pemerintah tetapi juga milik sendiri dan gaduhan dari petani lain. Sebagian besar $(71 \%)$ induk sapi responden dikawinkan secara alami dengan pejantan yang ada di sekitar kediaman mereka tanpa memperhatikan kualitasnya. Hal ini dilakukan karena terbatasnya jumlah pejantan yang tersedia. Dari 234 ekor induk yang dipelihara responden, hanya tersedia 14 ekor pejantan. Sementara itu pelaksanaan IB (Inseminasi Buatan) belum berjalan sebagaimana diharapkan. Pada Tabel 1 disajikan gambaran mengenai penerapan IB pada induk sapi yang diperoleh responden dari kredit pemerintah.

Dari 94 ekor induk yang diperoleh dari GM hanya 7 ekor (7 $\%$ yang menjadi akseptor IB. Sedangkan dari 100 ekor induk yang diperoleh dari KT didapat 50 ekor ( 50 $\%$ menjadi akseptor IB. Dengan demikian dari 96 ekor anak hasil IB sebagian besar $(88 \%)$ ditemui pada penerima KT. Hal ini antara lain disebabkan responden yang menerima KT mempunyai kesempatan untuk membeli induk sapi hasil persilangan seperti jenis Simental, Brahman dan Onggole, yang memiliki ukuran tubuh relatif besar. Dengan demikian induk yang diperoleh akan mendapat resiko distokia (kesulitan beranak) lebih kecil pada perkawinan dengan cara IB. Hal ini sejalan dengan temuan Anonim (2002) bahwa alasan $85 \%$ petani yang tidak menerapkan IB adalah untuk mengurangi resiko distokia. Sungguhpun jumlah induk jenis Persilangan 
hanya 26 ekor (13\%) dari populasi induk yang diamati, tetapi mampu memberikan kontribusi sebesar $50 \%$ dari jumlah anak hasil IB yang dihasilkan oleh seluruh responden.

Selain itu keengganan peternak penerima GM untuk menerapkan IB sangat erat kaitannya dengan pola kredit yang diterapkan. Dengan pola GM, dimana peternak membayar kredit dengan keturunan temak tanpa mempertimbangkan mutu dan nilainya, maka peningkatan mutu genetis hasil keturunan ternak melalui IB tidak memberikan keuntungan apaapa bagi peternak. Lain halnya pada penerima $\mathrm{KT}$, dengan menghasilkan keturunan yang bermutu secara langsung akan memberikan nilai tambah kepada mereka berupa harga ternak yang lebih tinggi.

\section{b. Kinerja Reproduksi}

Salah satu indikator yang menentukan keberhasilan pengembangan pembibit sapi potong adalah Angka Kelahiran, yaitu jumlah anak yang diperoleh selama periode tertentu. Angka ini dipengaruhi oleh dua faktor yaitu Masa Tunggu (jarak waktu antara ternak diterima sampai dengan saat beranak pertama) dan Jarak Beranak (calving interval), yaitu jarak waktu antara dua beranak normal. Pada Tabel 2 disajikan data kinerja reproduksi induk sapi kredit scjak diterima responden sampai saat pengumpulan data. Dari data pada Tabel 1 diperlihatkan bahwa penerima GM membutuhkan Masa Tunggu (untuk mendapatkan anak pertama) yang sangat nyata lebih lama dibandingkan dengan penerima $\mathrm{KT}$ dengan nilai-p (2-railed $)=0,00$ lebih kecil dari 0,01 level of significant $(\alpha)$.

Tabel 1. Penerapan IB oleh Responden pada Induk yang Diperoleh dari Kredit Pemerintah

\begin{tabular}{lrrrrr}
\hline \multirow{2}{*}{ Jumlah } & \multicolumn{2}{c}{ GM (Gaduhan Murni) } & \multicolumn{2}{c}{ KT (Kredit Tunai) } & \multirow{2}{*}{ Jumlah } \\
\cline { 2 - 5 } & \multicolumn{1}{c}{ Bali } & Persilangan & Bali & Persilangan & \\
\hline Induk & 94 & 0 & 74 & 26 & 194 \\
Akseptor IB & 7 & 0 & 24 & 26 & 57 \\
Anak Kawin Alam & 159 & 0 & 95 & 1 & 255 \\
Anak IB & 11 & 0 & 35 & 45 & 91 \\
\hline
\end{tabular}

Keterangan: Bali = induk sapi jenis Bali; Persilangan = induk sapi hasil persilangan

Tabel 2. Kinerja Reproduksi Induk Sapi yang Diperoleh dari Kredit Pemerintah

\begin{tabular}{lrrr}
\hline \multirow{2}{*}{ Indikator } & \multicolumn{2}{c}{ Pola Kredit } & \multirow{2}{*}{ Nilai-p } \\
\cline { 2 - 3 } & \multicolumn{1}{c}{ GM (Gaduhan } & KT (Kredit Tunai) & \\
\hline Masa Tunggu (bulan) & $25,4 \pm 8,6(\mathrm{n}=90)$ & $13,0 \pm 6,6(\mathrm{n}=99)$ & 0,00 \\
Jarak Beranak (bulan) & $12,1 \pm 2,7(\mathrm{n}=35)$ & $12,2 \pm 1,6(\mathrm{n}=30)$ & 0,87 \\
Angka Kelahiran (ekor/tahun) & $0,51 \pm 0,18(\mathrm{n}=90)$ & $0,84 \pm 0,80(\mathrm{n}=99)$ & 0,00 \\
\hline
\end{tabular}


Responden yang menerima induk dari kredit dengan pola GM membutuhkan rataan waktu hampir dua tahun untuk mendapatkan keturunan pertama, sedang responden yang menerima KT hanya membutuhkan waktu sekitar satu tahun saja. Hasil analisis terhadap Jarak Beranak pada kedua kelompok ini tidak ditemui adanya berbedaan yang nyata. Dengan demikian maka Angka Kelahiran induk sapi pada kelompok penerima GM secara sangat nyata lebih rendah dibandingkan dengan penerima KT dengan nilai-p (2-tailed) $=0,00$, Jarak Beranak yang diperoleh pada penelitian ini mempelihatkan capaian yang cukup baik dibandingkan dengan temuan Lubis dan Sitepu (1998) pada sapi Bali di Lampung Utara dengan Jarak Beranak antara 351 - 440 hari, maupun yang dilaporkan Tanari (2001) pada sapi jenis yang sama yaitu dengan Jarak Beranak 12,19 $\pm 0,06$ bulan.

Panjangnya Masa Tunggu ternak yang peroleh responden dari pola GM disebabkan karena ternak gaduhan yang diterima umumnya masih muda dan sering disertai dengan kondisi tubuh yang kurang baik. Ternak gaduhan yang dipelihara olch responden adalah hasil keturunan (redistribusi) ternak pemerintah penyebaran tahun $1983-1989$. Dengan sistem pembayaran kredit dalam bentuk ternak hasil keturunan akan cenderung mendorong petani tidak terlalu memperhatikan mutu ternak yang mereka hasilkan. Oleh karena itu telah terjadi penurunan mutu ternak hasil redistribusi secara bertahap pada ternak kredit pola GM. Sementara itu responden penerima KT lebih memiliki keleluasaan dalam memperoleh ternak yang siap kawin karena peternak mempunyai kesempatan membeli sendiri ataupun bersama kelompok untuk mendapatkan bibit ternak yang lebih baik. Bahkan ditemui sejumlah responden yang membeli induk yang sudah bunting bahkan membeli induk beserta dengan anak yang baru dilahirkan.

Tingkat kematian anak pra sapih (pedet) sebanyak 11 ekor (6,5\% dari angka kelahiran) pada penerima GM, sedangkan pada penerima KT sebanyak 3 ekor $(1,7 \%)$. Angka ini menunjukkan bahwa tingkat kematian pedet pada penerima KT sedikit lebih baik dibandingkan dengan pada penerima GM. Sungguhpun demikian secara umum capaian tersebut lebih baik dibandingkan dengan tingkat kematian pedet sapi Bali yang dilaporkan Tanari (2001) yaitu sebesar $7,26-7,33 \%$.

\section{Pakan}

Pola pemeliharaan temak yang diterapkan responden di lokasi penelitian hampir merata yaitu semi intensif dimana ternak dikandang pada malam hari dan dipadangkan (diikatkan di padang penggembalaan) pada waktu siang hari. Pakan diberikan di kandang, selain itu ternak juga mendapatkan tambahan hijauan pada saat dipadangkan. Hijauan yang diberikan umumnya adalah hijauan alam, dengan mutu yang relatif rendah, yang dicampur dengan rumput unggul (bagi responden yang menanam rumput unggul). Rumput alam diambil responden di lokasi yang berjarak antara $1 \mathrm{~km}$ sampai dengan $20 \mathrm{~km}$, dengan rataan $3,6 \mathrm{~km}$ dari kediaman responden. Sebagian responden juga menanam rumput unggul di sekitar rumah maupun di ladang tetapi dalam jumlah yang sangat terbatas. Sedangkan pemberian 
konsentrat hanya dilakukan oleh sebagian kecil responden dengan jumlah sangat terbatas mengingat tidak tersedianya sumber konsentrat di lokasi setempat. Pada tabel 3 disajikan jumlah responden yang menanam rumput unggul dan memberikan konsentrat kepada ternaknya.

Dari angka yang diperoleh terlihat bahwa lebih banyak responden penerima KT menanam rumput unggul serta memberikan konsentrat kepada ternak mereka dibandingkan dengan responden penerima GM. Hal ini dapat disebabkan oleh dua hal. Pertama, penerima KT lebih memiliki motivasi untuk menyediakan pakan yang berkualitas karena mereka lebih merasakan keuntungan dari usaha ternak yang dikelolanya. Kedua, penerima KT dibina melalui kelompok tani sehingga akan menciptakan kontrol sosial yang lebih baik dalam pengelolaan ternak mereka. Sementara itu pada penerima GM yang ditemui sebagian besar tidak tergabung dalam kelompok tani.

\section{Manajemen}

Manajemen pengembangan sapi potong mencakup aspek yang sangat luas antara lain pengaturan perkawinan, pencegahan penyakit sampai pada pengelolaan pemasaran. Pada peternak kecil manajemen ini tergambar dari perilaku petani dalam pengelolaan usahatani yang mereka kembangkan. Tentunya tidak mudah untuk mengamati perilaku sehari hari petani dalam pengelolaan ternak mereka. Oleh karena itu digunakan metode yang lebih sederhana yaitu melalui penilaian Sikap terhadap Pengembangan Sapi Potong. Sikap (attitude) merupakan suatu konsep psikologi sosial yang sering digunakan para ahli untuk melihat kecenderung seseorang untuk perilaku tertentu. Oleh Triandis (1971) ditegaskan bahwa konsepsi sikap merupakan perwujudan adanya konsistensi antara pemikiran (thinking), perasaan (feeling) dan perbuatan (acting). Hal ini dipertegas oleh Ancok (1997) tentang adanya hubungan antara pengetahuan, sikap, niat dan perilaku. Metode ini telah digunakan untuk melihat perilaku petani dalam penerapan suatu inovasi oleh Wijayanto (2005) dan Zahid (1997). Dalam konteks penelitian ini digunakan asumsi bahwa semakin positif sikap seseorang terhadap pengembangan sapi potong maka akan semakin baik manajemen pemeliharaan ternak yang diterapkan.

Dari hasil Uji Chi Square terhadap sebaran nilai sikap responden penerima GM dan KT sebagaimana disajikan pada Tabel 4 diperoleh nilaip (2-tailed) $=0,00$. Hal ini menunjukkan bahwa responden penerima KT mempunyai pengetahuan, persepsi dan kecenderungan berperilaku yang lebih positif terhadap pengembangan sapi potong dibandingkan penerima GM. Lebih positifnya sikap penerima $\mathrm{KT}$ ini erat kaitannya dengan manfaat yang mereka terima dari pengem-bangan sapi potong (Ancok, 1997). Dengan sistem kredit yang diterapkan maka penerima KT merasa men-dapatkan lebih banyak nilai tambah dibandingkan pada penerima GM sehingga motivasi untuk mengembangkan ternak menjadi lebih meningkat. Soerachman et al (2004) melaporkan bahwa kredit ternak dengan pola tunai melalui dana BPLM, saat ini disebut PMUK, di Lampung lebih berkembang diban- 
dingkan dengan pola gaduhan. Sementara itu Sariubang dan Pasambe (2004) menemukan bahwa peternak di Sulawesi Selatan lebih menyukai kredit pola BPLM daripada pola tradisional dengan sistem gaduhan. Sungguhpun demikian dari hasil uji reliabilitas terhadap instrumen penelitian didapat nilai Cronbach"s Alpha sebesar 0,543. Angka ini lebih kecil dari 0,60 yang memberikan indikasi bahwa konstruk pernyataan yang disusun pada instrumen penelitian memiliki tingkat reliabilitas rendah (Nugroho, 2005).

\section{Kesimpulan}

Pola kredit pengadaan bibit temak sapi potong untuk peternak kecil di
Provinsi Jambi mempunyai pengaruh yang sangat nyata terhadap kinerja pengembangan ternak yang dikaji. Dari hasil penelitian diperoleh bahwa pola KT memberikan dampak yang lebih positif terhadap pengembangan pembibitan sapi potong pada peternak kecil dibandingkan dengan pola GM. $\mathrm{Hal}$ ini dibuktikan dengan penerapan program peningkatan mutu genetis bibit, kinerja reproduksi ternak, tingkat penerapan teknologi pakan yang lebih tinggi serta sikap responden terhadap pengembangan sapi potong yang lebih positif pada responden penerima kredit dengan pola KT dibandingkan dengan penerima kredit pola GM.

Tabel 3. Jumlah Responden yang Menanam Rumput Unggul dan Memberikan Konsentrat untuk Ternaknya

\begin{tabular}{lrrr}
\hline \multicolumn{1}{c}{ Perlakuan } & $\begin{array}{c}\text { GM (Gaduhan } \\
\text { Murni) }\end{array}$ & \multicolumn{1}{c}{$\begin{array}{c}\text { KT (Kredit } \\
\text { Tunai) }\end{array}$} & Jumlah \\
\hline $\begin{array}{l}\text { Penanaman } \\
\text { Unggul }\end{array}$ & $28(31 \%)$ & $65(71 \%)$ & $93(51 \%)$ \\
- Menanam & $62(69 \%)$ & $27(29 \%)$ & $89(49 \%)$ \\
- Tidak menanam & & & \\
\hline $\begin{array}{l}\text { Pemberian Konsentrat } \\
\text { - Diberi }\end{array}$ & $16(18 \%)$ & $42(46 \%)$ & $58(32 \%)$ \\
- Tidak diberi & $74(82 \%)$ & $50(54 \%)$ & $124(68 \%)$ \\
\hline
\end{tabular}

Tabel 4. Sebaran Jumlah Aitem Sikap Responden terhadap Pengembangan Sapi Potong

\begin{tabular}{lrrrr} 
& \multicolumn{4}{c}{ Nilai Sikap } \\
\cline { 2 - 5 } \multicolumn{1}{c}{ Pola Kredit } & -1 & 0 & 1 \\
\hline GM (Gaduhan Murni) & 211 & 60 & 539 \\
KT (Kredit Tunai) & 130 & 15 & 692 \\
\hline Total & 341 & 75 & 1.231 \\
\hline
\end{tabular}




\section{DAFTAR PUSTAKA}

Ancok, D, 1997. Teknik Penyusunan Skala Pengukur. Pusat Penelitian Kependudukan Universitas Gadjah Mada. Yogyakarta.

Anonim. 2002. Bahan Seminar: Hasil Penelitian Kajian Penerapan Teknologi Inseminasi Buatan dalam Provinsi Jambi. Dinas Peternakan Provinsi Jambi.

Anonim. 2006. Pedoman Umum Pemberdayaan Masyarakat Pertanian melalui Penguatan Modal Usaha Kelompok. Sekretaris Jenderal Dep. Pertanian.

Azwar, S. 1995. Sikap Manusia, Teori dan Pengukurannya. Pustaka Pelajar. Yogyakarta.

Carlson, W.L. dan B. Thorne. 1997. Applied Statistical Methods. Prentice Hall. USA.

Kuswandi dan E. Mutiara. 2004. Statistik Berbasis Komputer untuk Orang-orang Nonstatistik. Elex Media Komputindo. Jakarta.

Lubis, A.M. dan P. Sitepu. 1998. Performan Reproduksi Sapi Bali dan Potensinya sebagai Breeding Stock di Kecamatan Lampung Utara. Prosiding Seminar Nasional Peternakan dan Veteriner 1-2 Desember 1998. Hal. 215-221. Pusat Penelitian Peternakan. Bogor.

Nasution, S. 2004. Metode Research (Penelitian Ilmiah). Cetakan Ketujuh. Bumi Aksara. Jakarta.
Nugroho, B.A. 2005. Strategi Jitu Memilih Metode Statistik Penelitian dengan SPSS. Penerbit Andi. Yogyakarta.

Saragih, B. 1998. Agribisnis Berbasis Peternakan. Pusat Studi Pembangunan. Lembaga Penelitian Institut Pertanian Bogor.

Sariubang, M dan D. Pasambe. 2004. Pergeseran Pola Gaduhan Temak Sapi di Sulawesi Selatan. Prosiding Seminar Sistem dan Kelembagaan Usahatani Tanaman - Temak 2004. Hal. 309 - 316. Balitbang Departemen Pertanian.

Soerachman, A. Prabowo dan Kuswanto. 2004. Pola Gaduhan Ternak Sapi di Lampung. Prosiding Seminar Sistem dan Kelembagaan Usahatani Tanaman - Ternak 2004. Hal. $302-308$. Balitbang Departemen Pertanian.

Soekartawi et al. 1986, Ilmu Usahatani dan Penelitian untuk Pengembangan Petani Kecil. UI Press. Jakarta.

Suryabrata, S, 1998. Pengembangan Alat Ukur Psikologis. Direktorat Jenderal Pendidikan Tinggi. Departemen Pendidikan dan Kebudayaan. Jakarta.

Tanari, M. 2001. Usaha Pengembangan Sapi Bali sebgai Ternak Lokal dalam Menunjang Pemenuhan Kebutuhan Protein Asal Hewan di Indonesia. Makalah Falsafah Sain. Dari Web Site 
Wijayanto, B. 2005. Tingkat Adopsi Pengelolaan Tanaman dan Sumberdaya Terpadu Padi Sawah Irigasi di Kabupaten Lampung Tengah. Sekolah Pasca Sarjana Universitas Gadjah Mada. Tesis (Tidak Dipublikasi).
Zahid, A. 1997. Hubungan Karakteristik Peternak Sapi Perah dengan Sikap dan Perilaku Aktual dalam Pengelolaan Limbah Peternakan. Program Pasca Sarjana Institut Pertanian Bogor. Tesis (Tidak Dipublikasi).

Alamat Korespondensi : Husni Jamal Balitbangda Provinsi Jambi

Jl. R.M. Nur Atmadibrata no. 5 Telanaipura Jambi Telp : (0741) 63461 - Faks. (0741) 62455 HP : 08127414630

Diterima: 22 Januari 2007, Disetujui: 12 Februari 2007 